\title{
Job Satisfaction of Commercial Bank Employees in Bangladesh: An Empirical Study
}

\section{Dhanonjoy Kumar}

Associate Professor, Department of Management, Islamic University, Kushtia -7003, BANGLADESH

"Corresponding Contact:

Email: djoysk@yahoo.com

\begin{abstract}
The progress of any organization is absolutely dependent on the skillful utilization of its human resources. It is not a machine but man - thoroughly motivated and completely dedicated that helps a firm's profit curve soaring upward. Human resources are the only strategic resources that can make a notable difference between two or more firms in respect of their goal-attainment. Job satisfaction of employees has been recognized now-a-days as a pre-requisite for achieving the organization's goals. In fact, it makes a significant contribution towards enhancing the firm's overall performance. It is well accepted that the higher the level of job satisfaction of employees, the greater is the contribution of employees to the organization. The present paper seeks to analyze job satisfaction of bank employees in Bangladesh. It focuses on the relative importance of job satisfaction factors and their impact on the overall job satisfaction of employees. In this study the Minnesota Satisfaction Questionnaire (MSQ- Long Form) was used in measuring satisfaction levels of 20 job facets and general job satisfaction. While tackling the issue addressed in the study relevant statistical tools and techniques were applied at appropriate places. The study revealed that the majority of the respondents were found satisfied with their jobs. It also observes that all job-related variables had a positive influence on the job satisfaction.
\end{abstract}

Keywords: Job Satisfaction, Bank Employees, Human Resources, Bank

$12 / 14 / 2016$

Source of Support: Nil, No Conflict of Interest: Declared

How to Cite: Kumar D. 2016. Job Satisfaction of Commercial Bank Employees in Bangladesh: An Empirical Study ABC Journal of Advanced Research, 5, 61-70.

This article is is licensed under a Creative Commons Attribution-NonCommercial 4.0 International License.

Attribution-NonCommercial (CC BY-NC) license lets others remix, tweak, and build upon work non-commercially,

and although the new works must also acknowledge \& be non-commercial.

\section{INTRODUCTION}

Job satisfaction is one of the most widely discussed and enthusiastically studied constructs in such related disciplines as industrial psychology, organizational behavior, personnel and human resource management and organizational management. At present job satisfaction has been a vital issue. People are interested to work in the organization as well as the services where they get more satisfaction. It is human behavior. But in reality how far such job satisfaction is ensured in different jobs. The research interest is to analyze job satisfaction from an organizational perspective. This study has tried to reveal the job satisfaction among 
the bank employees in Bangladesh. Banks are service providing organizations. People working here find to be monotonous and risky. Everywhere in this world, banking industry is playing a vital role in the economic development. Banking business of Bangladesh is one of the major service sectors, which contributes significantly to the national economy. The sector comprises a number of banks. In terms of ownership it can be classified into four major categories, namely- State-owned Commercial Banks (SCBs), Specialized Banks (SBS), Private Commercial Banks (PCBs), and Foreign Commercial Banks (FCBs). With the opening up of the economy of Bangladesh, a dramatic change has been observed both in manufacturing and service sectors. This has brought higher employment opportunities, increases in income level, and changes in consumption pattern. All these have resulted in an emergence of a competitive environment in the country.

\section{LITERATURE REVIEW}

Many researchers have conducted research works on different aspects on job satisfaction of bank employees in Bangladesh and aboard. Several important empirical research findings have been taken into consideration.

Hossain (2000) found that the public sector bank employees were in a better position in terms of their job satisfaction than the private bank employees and the executives were more satisfied than the non-executives. Job satisfaction had significant positive correlation with the performance but significant negative correlation with job stress and propensity to quit the job.

Islam and Saha (2001) concluded that job satisfaction of bank officers was significantly dependent upon salary, efficiency in work, fringe benefit, supervision quality, and co-worker relations. The remaining three factors, leadership style, loyalty to bank, and work ability do not have significant statistical evidence to improve the job satisfaction of bank officers.

Hanif and Kamal (2009) found that the job satisfaction of bank officers was significantly dependent upon pay, promotion opportunities, rewards, relation with boss and coworkers. It was evident that the dependent variable satisfaction with pay has the expected positive effect on job satisfaction.

Shrivastava and Purang (2009) suggested that the public sector bank needs to increase employees' pay satisfaction by introducing a differential pay system based on one's merit and effort. Also, human resource practices must be efficiently and literally used to enrich one's job. HR practices can be potentially used to chalk out employees' career paths by ensuring the proper disbursement of growth and training programs.

Khan et al. (2011) revealed that the compensation management had a direct and intense relation with the job satisfaction as well as job motivation. The results also revealed the changing trend of compensation plans in banking sector of Pakistan.

Ahmed et al. (2012) indicated that employees at the banking sector in Bangladesh expressed satisfaction with their co-workers, followed by the nature of the work and the supervision they receive. Opportunities for promotion and pay emerged as major sources of dissatisfaction.

Aloysius (2012) investigated the influence of demographic variables on job satisfaction of the bank employees. Job satisfaction was one of the major determinants of the physical, psychological and the social wellbeing of an employee. The main objective of the study was to find out the gender differences in the level of satisfaction where the work environment perceived as male dominated. 
Islam et al. (2012) investigated job satisfaction among employees of all public and private commercial banks in Bangladesh. The study determined that morale and job satisfaction plays a vital role in overall performance of the employees in the workplace. The study also determined that social status, supportive colleagues and feeling secure about the job were the top three best reasons for working in the banks. It was also determined that pay, decision making authority, and promotional policy were the three top priorities for improving the work environment.

Mojumder (2012) found that all HRM dimensions exercised in the private banking sector of Bangladesh were not satisfied to the employees equally. Most of the employees were dissatisfied with compensation package followed by reward and motivation, career growth, training and development, management style, job design and responsibilities.

Bader, Hasim and Zaharim (2013) reported a high level of job satisfaction in all aspects of their job. While the factors of gender, age and type of occupation have no significant effects on the level of job satisfaction, marital status, educational level, city and the duration of work have shown significant effects on the level of job satisfaction.

\section{ObJectives OF The Study}

The objectives of the study are as follows:

- To assess the overall level of job satisfaction of bank employees;

- To identify the factors and their relative importance to job satisfaction;

- To suggest appropriate polices for improvement and maintenance of bank employees job satisfaction.

\section{Methodology}

The study followed a quantitative approach to achieve the objectives of this study, which was descriptive in nature. There were five demographic variables such as age, gender, monthly income, experience and education, twenty independent variables taken for this study; ability utilization, achievement, activity, advancement, authority, company policy and practices, salary, co-workers relations, creativity, independence, moral values, recognition, responsibility, job security, social service, social status, supervision- human relations, variety works and working conditions to identify their impact on employees' job satisfaction. The dependent variable is job satisfaction of bank employees'. Simple random sampling was used to collect the data. Both primary and secondary data have been collected for the purpose of the study. The Minnesota Satisfaction Questionnaire, (MSQ- Long Form) was chosen to measure satisfaction levels of 20 job facets, and general job satisfaction (1=Very Dissatisfied, 2 = Dissatisfied, 3 = Neither Satisfied nor Dissatisfied, $4=$ Satisfied, $5=$ Very Satisfied) had been used in the survey. A total of 414 respondents (taking 207 from each division) were taken from two categories of banks employees in Bangladesh. Sample was drawn from 4 public sector banks (Sonali Bank Limited, Agrani Bank Limited, Janata Bank Limited, Rupali Bank Limited) and 4 private sector banks (Pubali Bank Limited, National Bank Limited, Dutch Bangla Bank Limited, and United Commercial Bank Limited) in eight districts namely Dhaka, Rajbari, Faridpur, Madaripur, Kushtia, Jhenaidah, Jessore and Khulna. Fisher formula was used in determining the minimum sample size. All types of data were processed through computer based Statistical Package for Social Science (SPSS) developed by Nie et al., (1975). Before feeding the data into a computer, all data were converted into numerical codes and the details of these coding were recorded in a code book. The Cronbach's alpha value $(\alpha)$ was found 0.9435 , which was higher than the minimum acceptable level 0.70 suggested by Nunnally (1978). The descriptive statistics was based on frequency percentage, mean, standard deviation, correlation analysis, and regression analysis. 


\section{CONCEPTUAL FRAMEWORK}

Job Satisfaction: The term 'job satisfaction' is used to describe how content an individual is with his or her job. Satisfaction is said to be an affective reaction and an attitude towards one's job. A person with a high level of job satisfaction has a positive attitude towards it, while a person dissatisfied with it rears up a negative attitude. When people speak of employee attitude, they usually are referring to job satisfaction which can be comprehensively defined as a satisfying emotional state resulting from the effects of a person's job experience. It is thought to be the reaction of an individual to a particular job (Lock, 1976). A happy employee is a productive employee. All organizations irrespective of nature and size need happy employees to run their operations smoothly and fruitfully.

Bank: Bank is a financial institution that collects society's surplus cash and gives a part of that as a loan to investors for earning a profit. So the bank is an intermediary institution that makes relationship between the owner of surplus savings and the investor of deficit capital. In this process, bank earns profit by receiving interest from the borrowers who want to take short-term and or long-term loans and making relatively lower interest payment to the depositors for providing their funds for use by the bank (Khan, A.R,. 2013).

\section{DATA ANALYSIS AND INTERPRETATION}

Table 1: Distribution of the Respondents by Age

\begin{tabular}{l|c|c|c}
\hline Class Interval (in years) & Frequency & Percent & Cumulative Percent \\
\hline $25-30$ & 155 & 37.400 & 37.400 \\
$31-35$ & 152 & 36.700 & 74.200 \\
$36-40$ & 23 & 5.600 & 79.700 \\
$41-45$ & 28 & 6.800 & 86.500 \\
46 to above & 56 & 13.500 & 100.000 \\
Total & $\mathbf{4 1 4}$ & $\mathbf{1 0 0 . 0 0 0}$ & \\
\hline
\end{tabular}

Source: Field Survey

The frequency distribution and percentages of the respondents' age (in year) are shown in table 1 . The majority of the banks employees, $37.4 \%$ belong to age group of $25-30$ years, $36.7 \%$ employees belong to the age group of 31-35 years. It is also observed that a moderate number, $13.5 \%$, of employees are with age of 46 and above. The youngest participant was 25 years of age and the oldest 59 years.

Table 2: Distribution of the Respondents by Gender

\begin{tabular}{l|c|c|c}
\hline Gender Type & Frequency & Percent & Cumulative Percent \\
\hline Male & 361 & 87.200 & 87.200 \\
Female & 53 & 12.800 & 100.000 \\
Total & $\mathbf{4 1 4}$ & $\mathbf{1 0 0 . 0 0 0}$ & \\
\hline
\end{tabular}

Source: Field Survey

Of the 414 respondents in this study, 361 or $87.2 \%$ were male and 53 or $12.8 \%$ were female.

Table 3: Distribution of the Respondents by Experience

\begin{tabular}{l|c|c|c}
\hline Class Interval (in years) & Frequency & Percent & Cumulative Percent \\
\hline $1-5$ & 264 & 63.800 & 63.800 \\
$6-10$ & 61 & 14.700 & 78.500 \\
$11-15$ & 23 & 5.600 & 84.100 \\
$16-20$ & 14 & 3.400 & 87.400 \\
21 to above & 52 & 12.600 & 100.000 \\
Total & $\mathbf{4 1 4}$ & $\mathbf{1 0 0 . 0 0 0}$ & \\
\hline
\end{tabular}

Source: Field Survey 
As shown in the table 3, the 52 or $12.6 \%$ of the respondents were highly experienced (more than 21 years). Majority 264 or $63.8 \%$ respondents have $1-5$ years job experience, 61 or $14.7 \%$ have the experience of $6-10$ years, 23 or $5.6 \%$ have experience of $11-15$ years and 14 or $3.4 \%$ have the experience of 16-20 years.

Table 4: Distribution of the Respondents by Monthly Income

\begin{tabular}{l|c|c|c}
\hline Class Interval (in taka) & Frequency & Percent & Cumulative Percent \\
\hline Less than 10000 & 20 & 4.800 & 4.800 \\
$10001-20000$ & 134 & 32.400 & 37.200 \\
20001-30000 & 118 & 28.500 & 65.700 \\
30001- 40000 & 76 & 18.400 & 84.100 \\
40001 to above & 66 & 15.900 & 100.000 \\
Total & $\mathbf{4 1 4}$ & $\mathbf{1 0 0 . 0 0 0}$ & \\
\hline
\end{tabular}

Source: Field Survey

Table 4 presents monthly salary information. Minimum number respondents, 66 or $15.9 \%$ earned monthly salary more than Tk. 40,000 . The majority 134 or $32.4 \%$ of the respondents earned a monthly salary in the range Tk. 10,001-20,000, 118 or $16 \%$ of the respondents earned a monthly salary Tk. 20001-30000, 20 or $4.8 \%$ of the respondents earned monthly salary Tk. less than 10,000 , and 76 or $18.4 \%$ of the respondents earned monthly salary ranged Tk. 30,001-40,000.

Table 5: Distribution of the Respondents by Educational Qualification

\begin{tabular}{l|c|c|c}
\hline \multicolumn{1}{c|}{ Level of Education } & Frequency & Percent & Cumulative Percent \\
\hline Masters and above degree & 357 & 86.200 & 86.200 \\
Bachelor degree & 38 & 9.200 & 95.400 \\
SSC and HSC pass & 19 & 4.600 & 100.000 \\
Total & $\mathbf{4 1 4}$ & $\mathbf{1 0 0 . 0 0 0}$ & \\
\hline
\end{tabular}

Source: Field Survey

Data in Table 5 shows that the majority of the bank employees, 357 or $86.2 \%$, obtained Master's degree and above and 38 or $9.2 \%$ have a bachelor degree. Very few bank employees 19 or $4.6 \%$ are under graduate.

Table 6: Distribution of Respondents in terms of Overall level of Job Satisfaction

\begin{tabular}{l|c|c|c}
\hline Level of Satisfaction/Dissatisfaction & Frequency & Percent & Cumulative Percent \\
\hline Very dissatisfied & 14 & 3.400 & 3.400 \\
Dissatisfied & 29 & 7.000 & 10.400 \\
Neither dissatisfied nor satisfied & 139 & 33.600 & 44.000 \\
Satisfied & 201 & 48.600 & 92.500 \\
Very satisfied & 31 & 7.500 & 100.000 \\
Total & $\mathbf{4 1 4}$ & $\mathbf{1 0 0 . 0 0 0}$ & \\
\hline
\end{tabular}

\section{Source: Field Survey}

The above table provides the general satisfaction level information. The table 6 shows that majority of respondents 201 or $48.6 \%$ are satisfied, 31 or $7.5 \%$ respondents are very satisfied, 139 or $33.6 \%$ respondents are neither dissatisfied or nor satisfied, 29 or $7 \%$ respondents are dissatisfied, and 14 or $3.4 \%$ respondents are very dissatisfied. 
Table 7: Hierarchy of job related variables according to mean

\begin{tabular}{|l|c|c|}
\hline Name of Variables & Mean & Std. Deviation \\
\hline Moral Values & 3.98 & 1.033 \\
\hline Activity & 3.91 & .986 \\
\hline Responsibility & 3.91 & .965 \\
\hline Achievement & 3.90 & .942 \\
\hline Co-Worker & 3.90 & .940 \\
\hline Social Status & 3.89 & .984 \\
\hline Social Service & 3.78 & 1.033 \\
\hline Security & 3.77 & 1.015 \\
\hline Authority & 3.76 & .992 \\
\hline Supervision Human Relations & 3.73 & .902 \\
\hline Recognition & 3.68 & .982 \\
\hline Supervision Technical & 3.68 & .986 \\
\hline Ability Utilization & 3.59 & .957 \\
\hline Advancement & 3.58 & 1.031 \\
\hline Creativity & 3.58 & 1.007 \\
\hline Independence & 3.51 & 1.029 \\
\hline Working Conditions & 3.51 & 1.100 \\
\hline Company Policies and Practices & 3.45 & .994 \\
\hline Variety & 3.42 & 1.047 \\
\hline Salary & 3.18 & 1.209 \\
\hline
\end{tabular}

Source: Field Survey

The mean and standard deviation of the selected variables are given in $2^{\text {nd }}$ and $3^{\text {rd }}$ column of the table 7 . Among the 20 job related variables, the moral values possesses the highest mean value (3.98) and the salary possesses the lowest mean value (3.18).

Table 8: Correlations of Job Related Variables and Dependent Variables (General satisfaction)

\begin{tabular}{|c|c|c|c|c|c|c|c|c|c|c|c|c|c|c|c|c|c|c|c|c|c|}
\hline & 1 & 2 & 3 & 4 & 5 & 6 & 7 & 8 & 9 & 10 & 11 & 12 & 13 & 14 & 15 & 16 & 17 & 18 & 19 & 20 & 21 \\
\hline 1. & 1 & .603 & .585 & .573 & .576 & .586 & .571 & .570 & .470 & .602 & .612 & .504 & .586 & .552 & .381 & .549 & .577 & .548 & .541 & .589 & .642 \\
\hline 2. & & 1 & .552 & .541 & .490 & .483 & .515 & .519 & .361 & .545 & .462 & .370 & .400 & .452 & .261 & .447 & .451 & .445 & .439 & .440 & .481 \\
\hline 3. & & & 1 & .574 & .493 & .496 & .438 & .363 & .396 & .472 & .437 & .386 & .417 & .464 & .246 & .462 & .507 & .365 & .332 & .415 & .366 \\
\hline 4. & & & & 1 & .513 & .532 & .453 & .395 & .403 & .486 & .401 & .398 & .420 & .498 & .308 & .444 & .444 & .397 & .394 & .416 & .370 \\
\hline 5. & & & & & 1 & .501 & .492 & .448 & .354 & .484 & .432 & .393 & .474 & .390 & .277 & .422 & .499 & .402 & .307 & .414 & .357 \\
\hline 6. & & & & & & 1 & .531 & .387 & .499 & .592 & .578 & .487 & .471 & .591 & .403 & .432 & .437 & .469 & .451 & .457 & .407 \\
\hline 7. & & & & & & & 1 & .467 & .413 & .550 & .510 & .422 & .448 & .424 & .310 & .419 & .453 & .447 & .437 & .484 & .446 \\
\hline 8. & & & & & & & & 1 & .367 & .439 & .458 & .285 & .447 & .315 & .242 & .391 & .427 & .310 & .360 & .429 & .548 \\
\hline 9. & & & & & & & & & 1 & .457 & .420 & .397 & .403 & .457 & .336 & .374 & .342 & .448 & .379 & .300 & .365 \\
\hline 10. & & & & & & & & & & 1 & .658 & .482 & .469 & .513 & .328 & .453 & .469 & .486 & .435 & .558 & .419 \\
\hline 11. & & & & & & & & & & & 1 & .480 & .525 & .445 & .353 & .464 & .438 & .513 & .492 & .529 & .457 \\
\hline 12. & & & & & & & & & & & & 1 & .510 & .615 & .292 & .400 & .465 & .489 & .470 & .392 & .359 \\
\hline 13. & & & & & & & & & & & & & 1 & .482 & .336 & .412 & .470 & .434 & .422 & .475 & .465 \\
\hline 14. & & & & & & & & & & & & & & 1 & .356 & .463 & .453 & .508 & .430 & .398 & .334 \\
\hline 15. & & & & & & & & & & & & & & & 1 & .334 & .297 & .327 & .299 & .239 & .229 \\
\hline 16. & & & & & & & & & & & & & & & & 1 & .519 & .460 & .395 & .450 & .414 \\
\hline 17. & & & & & & & & & & & & & & & & & 1 & .550 & .424 & .477 & .431 \\
\hline 18. & & & & & & & & & & & & & & & & & & 1 & .621 & .498 & .440 \\
\hline 19. & & & & & & & & & & & & & & & & & & & 1 & .513 & .541 \\
\hline 20. & & & & & & & & & & & & & & & & & & & & 1 & .573 \\
\hline 21. & & & & & & & & & & & & & & & & & & & & & 1 \\
\hline
\end{tabular}

Source: Field Survey 
Correlation is significant at the 0.01 level (2-tailed)

(N: B: 1 = General Satisfaction, 2 = Ability Utilization, 3 = Achievement, 4 = Activity, $5=$ Advancement, $6=$ Authority, $7=$ Company policy and practices, $8=$ Salary, $9=$ Co-worker, $10=$ Creativity, $11=$ Independence, $12=$ Moral Values, $13=$ Recognition, $14=$ Responsibility, 15 = Security, 16 = Social Service, 17 = Social Status, $18=$ Supervision human relations, 19 = Supervision technical, $20=$ Variety, $21=$ Working conditions.)

Table-8 Correlations of Job related Variables and Dependent Variables (General Satisfaction) are given below into the tables. The table shows the correlation between overall job satisfaction, ability utilization, achievement, activity, advancement, authority, company policy and practices, salary, co-workers relations, creativity, independence, moral values, recognition, responsibility, job security, social service, social status, supervision- human relations, variety works and working conditions. The relationship is significant at $\alpha 0.01$. The value of correlation coefficient for ability utilization, achievement, activity, advancement, authority, company policy and practices, salary, co-workers relations, creativity, independence, moral values, recognition, responsibility, job security, social service, social status, supervision- human relations, variety works and working conditions are $0.603,0.585,0.573,0.576,0.586,0.571,0.570,0.470,0.602,0.612,0.504,0.586,0.552,0.381$, $0.549,0.577,0.548,0.541,0.589$ and 0.642 . All independent variables show the positive relationships between overall job satisfactions. Working condition shows the highest positive relationships between job satisfactions. Its value is 0.642 . Job security shows the lowest positive relationships between job satisfactions. Its value is 0.381 .

Table: 9(a) and 9(b) Linear Regression Analyses of Bank Employees' job satisfaction with compensation factors

9(a) Model Summary

\begin{tabular}{|c|c|c|c|}
\hline R & R Square & Adjusted R Square & Std. Error of the Estimate \\
\hline $.841(\mathrm{a})$ & .707 & .692 & .479 \\
\hline
\end{tabular}

a Predictors: (Constant) Twenty Independent Variables.

9(b) Coefficients

\begin{tabular}{|l|c|c|c|c|c|}
\hline & \multicolumn{2}{|c|}{ Un standardized Coefficients } & Standardized Coefficients & $\mathrm{t}$ & Sig. \\
\hline & $\mathrm{B}$ & Std. Error & Beta & & \\
\hline (Constant) & -.244 & .140 & & -1.743 & .082 \\
\hline Ability Utilization & .048 & .036 & .053 & 1.322 & .187 \\
\hline Achievement & .104 & .035 & .114 & 2.952 & .003 \\
\hline Activity & .059 & .034 & .067 & 1.745 & .082 \\
\hline Advancement & .086 & .031 & .103 & 2.742 & .006 \\
\hline Authority & .012 & .036 & .013 & .321 & .748 \\
\hline $\begin{array}{l}\text { Company Policies } \\
\text { and Practices }\end{array}$ & .027 & .033 & .031 & .816 & .415 \\
\hline Compensation & .058 & .027 & .081 & 2.155 & .032 \\
\hline Co-Worker & .003 & .032 & .003 & .094 & .925 \\
\hline Creativity & .029 & .037 & .034 & .785 & .433 \\
\hline Independence & .080 & .035 & .095 & 2.276 & .023 \\
\hline Moral Values & .001 & .032 & .002 & .046 & .963 \\
\hline Recognition & .062 & .033 & .070 & 1.865 & .063 \\
\hline Responsibility & .072 & .037 & .081 & 1.961 & .051 \\
\hline Security & .040 & .027 & .047 & 1.514 & .131 \\
\hline
\end{tabular}




\begin{tabular}{|l|c|c|c|c|c|}
\hline Social Service & .036 & .030 & .043 & 1.189 & .235 \\
\hline Social Status & .041 & .034 & .047 & 1.217 & .224 \\
\hline $\begin{array}{l}\text { Supervision } \\
\text { Human Relations }\end{array}$ & .028 & .039 & .029 & .697 & .468 \\
\hline $\begin{array}{l}\text { Supervision } \\
\text { Technical }\end{array}$ & .028 & .035 & .032 & .811 & .418 \\
\hline Variety & .035 & .033 & .043 & 1.082 & .280 \\
\hline $\begin{array}{l}\text { Working } \\
\text { Conditions }\end{array}$ & .179 & .031 & .228 & 5.790 & .000 \\
\hline
\end{tabular}

Dependent Variable: General Job Satisfaction

Tables 9(a) and 9(b) represent the regression analysis. The analysis shows that the R-Square value is 0.707 . It indicates that a good proportion of variation $(70.70 \%)$ exists between the dependent variable (teachers' job satisfaction) is explained by the total variation of the 20 independent variables. From all the independent variables significant values of only five variables, like - job achievement, job advancement, compensation, independence and working conditions are less than the $P$ value 0.05 . Another three independent variables like job activity, recognition and job responsibility significant values are less than the P value 0.10 . It indicates that the bank employees think job achievement, job advancement, compensation, independence, working conditions, job activity, recognition and job responsibility are the important compensation factors for their profession.

\section{MAJOR FINDINGS OF THE STUDY}

The main findings of the study conducted on "Job Satisfaction of Commercial Bank Employees is summarized below:

- The overall level of job satisfaction from 414 respondents 201 are satisfied, 31 are very satisfied, 139 are neither dissatisfied nor satisfied, 29 are dissatisfied nor 14 are very dissatisfied.

- There is a significant positive correlation between job satisfaction and job-related variables.

- The study shows that significant differences exist between employees of Public Sector Banks and Private Sector Banks regarding pay and increments.

- No significant difference exists between employees of Public Sector Banks and Private Sector Banks regarding job advancement.

- The study reveals that significant differences exist between employees of Public Sector Banks and Private Sector Banks regarding creativity and independence. The employees of Public Sector Banks are more satisfied with creativity and independence than that of Private Sector Banks employees.

- No significant difference exists between employees of Public Sector Banks and Private Sector Banks regarding recognition.

- The study reveals that significant differences exist between employees of Public Sector Banks and Private Sector Banks regarding working conditions. The employees of Private Sector Banks are more satisfied with working conditions than that of Public Sector Banks employees.

- The study shows that significant differences exist between employees of Public Sector Banks and Private Sector Banks regarding co-worker's relation. The employees of Private Sector Banks are more satisfied with co-worker's relation than that of Public Sector Banks employees. 


\section{Conclusion And Recommendations of the Study}

The findings of the study show majority of the respondents $56.10 \%$ (very satisfied and satisfied) are satisfied with their jobs. A close view of specific job facets indicates the highest satisfaction levels were occurring in the areas of moral values, activity, responsibility, achievement, co-workers' relations, social status and social service. Salary, a variety of work, company policies and practices, working conditions and independence are the facets reflecting the lowest satisfaction levels. Therefore the research suggests that job satisfaction can affect employees' morale, turnover, absenteeism and pro-social behavior, which can be crucial for organizational success. This very trend is equally applicable to the financial and nonfinancial organization. Job satisfaction of the employees in commercial banks is critical to their overall success.

\section{REFERENCES}

Ahmed AA and Dey MM. 2009. Bank Loan Officers' Perceptions of Corporate Financial Disclosure in the Banking Sector of Bangladesh: An Empirical Analysis, CIIT Proceedings 2nd CBRC. Lahore, Pakistan: COMSATS Institute of Information Technology.

Azad, M. R., Khan, W., \& Ahmed, A. A. A. (2011). HR Practices in Banking Sector on Perceived Employee Performance: A Case of Bangladesh. Eastern University Journal, 3(3), 30-39. https://doi.org/10.5281/zenodo.4043334

Ahmed AA. 2009. The Effect of Timeliness Regulation of Corporate Financial Reporting: Evidence from Banking Sector of Bangladesh Accounting and Management Information Systems, 8, 216 - 235.

Ahmed, S., Khalil, B., Rashed, C. A. A., Iqbal, M., \& Ferdoushi, N. 2012. Effects of Some Selected Factors on Job Satisfaction in Public Banking. IOSR Journal of Business and Management (IOSR-JBM). 5(3), 41-46.

Aloysius, S. M. C. M. 2012. The Demographic Variables and Their Impact on Job Satisfaction of Bank Employees, Proceedings of the Abstracts of Jaffna University International Research Conference (JUICE2012), 32-41.

Bader, H. A. M., Hasim, I. H. M., \& Zaharim, N. M. 2013. Job Satisfaction among Bank Employees in Eastern Libya. American International Journal of Social Science. 2(1), 30-44.

Brafield, A. H., \& Crocket, 1955. Employee Attitudes and Performance. Psychological Bulletin, 52, 396-428.

Fisher, A. A., Laing, J. E., \& Strocker, J. E. 1998. Handbook for Family Planning, Operation Research Design in Sampling. Population Council, 40-45.

Hakim, M. (2015). Organizational Culture and Job Satisfaction in Bank: Perceptions and Reactions of Employees.Global Disclosure of Economics and Business, 4(2), 167-180. Retrieved from http://iproclaim.my/archive/index.php/gdeb/article/view/92

Hanif, M. F. \& Kamal, Y. 2009. Pay and Job Satisfaction: A Comparative Analysis of Different Pakistani Commercial Banks Shaheed Zulfikar Ali Bhutto Institute of Science \& Technology (SZABIST). ISLAMABAD Paper presented in 9th National Research Conference held on 25th June 2009 at SZABIST, ISLAMABAD.

Hossain, M. M. 2000. Job Satisfaction of Commercial Bank Employees in Bangladesh: A Comparative Study of Private and Public Sectors. Indian Journal of Industrial Relations. 35(3), 347-361.

Islam, J. N., Mohajan, H. K., \& Datta, R. 2012. A Study on Job Satisfaction and Morale of Commercial Banks in Bangladesh. Int. J. Eco. Research.153-173.

Islam, J. N., Mohajan, H. K., Datta, R. 2012. A Study on Job Satisfaction and Morale of Commercial Banks in Bangladesh. Int. J. Eco. Research.153-173.

Islam, N. \& Saha, G. C. 2001. Job Satisfaction of Bank Officers in Bangladesh, ABAC Journal, Thailand, $21(3), 62-74$. 
Jashim Uddin, M., Chowdhury, M., Yasmin, M., \& Akter, A. (2016). Job Satisfaction of the Employees of the General Insurance Companies in Bangladesh. Global Disclosure of Economics and Business, 5(1), 7-18. Retrieved from http://i-proclaim.my/archive/index.php/gdeb/article/view/77

Khan, A. R. 2013. Bank Management: A Fund Emphasis. Mirpur, Dhaka: Brother Publication's.

Khan, R. I., Aslam, H. D., \& Lodhi, I. 2011. Compensation Management: A Strategic Conduit towards Achieving Employee Retention and Job Satisfaction in Banking Sector of Pakistan. Macro think Institute, International journal of human resource studies. 1(1), 89-97.

Kumar, D., Hossain, A., \& Gope, M. (2015). Role of Micro Credit Program in Empowering Rural Women in Bangladesh: A Study on Grameen Bank Bangladesh Limited. Asian Business Review, 3(4), 114-120.

Kumar, D., Hossain, M., \& Jebin, A. (2016). Organizational Commitment among the Employees of NGOs in Bangladesh: An Empirical Study. American Journal of Trade and Policy, 3(2), 55-60.

Locke, E. A. 1976. The Nature and Causes of Job Satisfaction. In M. D. Dunnette (Ed.), The Handbook of Industrial and Organizational Psychology, 1297-1349, Chicago, IL: Rand.

Mojumder, M. T. H. 2012. Human Resource Management Practices and Employees Satisfaction towards Private Banking Sector in Bangladesh. International Reviews of Management and Marketing. 2(1), 52-58.

Nasima, M., \& Alam, N. (2015). Job Satisfaction among Female Faculties of Different Public and Private Universities in Bangladesh: A Comparative Analysis. ABC Journal of Advanced Research, 4(1), 1726. Retrieved from http://i-proclaim.my/archive/index.php/abcjar/article/view/197

Norman, H. Nie. 1975. Statistical Package for the Social Sciences. New York: McGraw- Hill International Edition.

Nunnally, J. C. 1978. Psychometric Theory (2 ${ }^{\text {nd }}$ ed.), New York: McGraw Hill Company.

Shrivastava, A., \& Purang, P. 2009. Employee Perceptions of Job Satisfaction: Comparative Study on Indian Banks. Asian Academy of Management Journal. 14(2), 65-78. 